\title{
Partitioning and analyzing temporal variability of wash and bed material loads in a forest watershed in Iran
}

\author{
Seyed Hamidreza Sadeghi* and Mohamad Ali Zakeri \\ Department of Watershed Management Engineering, Faculty of Natural Resources, Tarbiat Modares University, \\ Noor 4641776489, Mazandaran, Iran. \\ ${ }^{*}$ Corresponding author.e-mail: sadeghi@modares.ac.ir
}

The amount of transported material from a hillslope or channel, mirrors the watershed health, which needs to be quantified. However, the contribution of different sediment sources to sediment load has not been adequately studied. In this study, 24 samples of suspended load, bed load and channel material were taken bi-weekly for a period of one year from the Kojour River of the Educational and Research Forest Watershed of Tarbiat Modares University in Iran. The suspended sediment concentration and particle-size distribution were determined. The total sediment load was then partitioned into bed load, wash load and suspended bed material load based on three criteria: (i) the upper limit of 63 micron, (ii) the Einstein method, and (iii) the lower limit of sediment particles in the channel material. The results suggested a significant contribution of wash load compared to suspended bed material and bed loads ratio of $96.8,2.65$ and $0.55 \%$, respectively. The ratio of suspended bed material load to wash load varied from $13.12 \%$ (the maximum) in winter to $11.02,2.70$ and $0.91 \%$ in autumn, spring and summer, respectively. The results also showed the effects of flow discharge on different components of sediment loads. While, the flow discharge significantly affected bed load and wash load with respective correlation coefficients $(r)$ of 0.520 and $0.464<r<0.535$ for three methods with significant level $(p)$ between 0.007 and 0.022 . It had little influence on suspended bed material load $(-0.243<r<0.277$ with $0.190<p<0.253)$.

\section{Introduction}

Every year, large amount of materials are washed from the surface watersheds and deposited behind dams, and inside craters, seas and oceans (Lefrançois et al. 2007; Singh et al. 2008). This leads to reduction in storage capacity of dams, increases flood risk, deteriorates water quality and ultimately results in dereliction of productive farm lands. Fine sediments play an important role in many river systems and their concentration affects the water quality (Novotny 1980; Milhous 1998). In addition, heavy metals and other pollutants are also transported along with fine sediments (Graf et al. 1991; Miller 1997; Sadeghi et al. 2012). The evaluation of soil erosion and sediment yield processes is, therefore, essential for better understanding of watershed fluvial systems and to adopt suitable management methods. The accurate estimation and prediction of sediments carried by the flow is also very important in water management projects (Hergault et al. 2010). Since, soil erosion and sediment production cycle is a complex natural process and is influenced by many factors, understanding the governing condition is essential for better management of the watersheds.

Keywords. Laser particle size distribution; sand and gravel mining; sediment dynamic; suspended sediment; watershed management. 
In rivers, the sediment particles move in the form of bed load or suspended load. The nature of particle movement depends on size, shape and specific weight of particles, and flow velocity and turbulence (Vanoni 1975). Moreover, depending upon the sources, sediments are divided into wash and bed material loads (Poplawski et al. 1989; Julien 2009; Wilcock et al. 2009). The sediment particles in wash loads are generally finer than those in bed material loads. The wash load is controlled by surface characteristics of watershed and contains fine particles that rarely exist in the river bed. These fine particles washed from watershed surface are always transported in suspension form (Poplawski et al. 1989; Yang and Simoes 2005; Wilcock et al. 2009). The wash load concentration at any reach of a river depends on frequency of fine sediment in neighbouring upland areas of waterways network, hydraulic features of splash and ground flow (Yuill and Gasparini 2011). The bed material load is mainly influenced by hydraulic characteristics of channel (e.g., slope, discharge and hydraulic power) and contains particles originated from the channel bed (Wilcock et al. 2009). In other words, wash load mainly depends on hydrologic conditions of the watershed, whereas bed material load often depends on hydraulic characteristics of river channel network.

Although the separation of sediments to bed and suspended loads has been conducted in previous studies (e.g., Walling et al. 2000), sediment classification from the origin has rarely been taken into account. Belperio (1979) calculated the total sediment load in Burdekin River in Australia. The mean annual wash load was estimated as 3.0 million tons of silt and clay by using a wash load rating curves. The mean annual bed material load was also calculated by theoretical bed load equation together with hydraulic parameters and found to be 0.45 million tons of sand. Poplawski et al. (1989) reported that more than $85 \%$ of the constituent particles of suspended load in the Flinder River, Australia, form particles with diameter smaller than $0.15 \mathrm{~mm}$. It showed that most of the suspended sediments have been originated from the upland areas of the watershed and therefore constituted wash loads. Walling et al. (2000) studied the characteristics of suspended sediment in the Tweed and the Humber watersheds during 19941998. They found that more than $95 \%$ of particles were smaller than 63 microns. In addition, studying sediment particle size variation during storm events showed a pulse of coarse sediment on the rising limb of the hydrograph that may reflect the remobilization of coarse channel bed sediment as flow velocity and shear stress increase. Finer sediment was transported subsequently during the hydrograph peak and on the falling limb. Periago and
Soto (2004) examined the factors affecting wash load transport in a head water catchment of 10.4 ha areas in NW Spain that produce maize and pasture using non-tillage methods. The results showed that the suspended sediment load decreased over successive floods to an extent independent of rainfall intensity. In addition, amount of wash load transport depends on surface run-off variation. Usually, amount of wash load increases in rainfall events occurring after dry periods. Yang and Simoes (2005) studied wash and bed material load transport in Yellow River in China by analysing 1160 samples collected from nine gauging stations along the middle and lower Yellow River by using unit stream power formula and the modified unit stream power formula. The results showed that two formulae could predict the wash load, bed material load and total sediment load. Moreover, the results showed that the capacity of bed material load transport was controlled by hydraulic conditions and amount of wash load. Yuill and Gasparini (2011) also revealed that, in a watershed in southern Arizona, the wash load concentration could be predicted by rainfall better than water discharge. Gellis (2013) studied the significant characteristics controlling the variability in storm generated suspended sediment loads and concentrations in four watersheds with different land uses in humid-tropical Puerto Rico. Results showed that the flow and rainfall between storm events affected sediment loads and concentrations. In watersheds with limited sediment availability (forest and pasture), the previous storm events supplied sediment to the channel. Besides that, sediment availability, expressed as sediment concentration per unit discharge, increased with human disturbance in the four study watersheds. Dai and Lu (2014) also critically reviewed spatial and temporal variations in grain size and rating curves, as well as the morphodynamic response of the channel and delta of the Yangtze River, China. They concluded that sediment supply, transport, mobilization and deposition in the Yangtze River were complicated by the heterogeneous nature of its morphology, climate and the progressive intensification of human activities. Singh et al. (2014) reported the highest rate of sediment loads in monsoon season followed by pre- and post-monsoon seasons in Gangotri glacier valley in the Uttarkashi district of Uttarakhand State, central Himalaya. Recently, Smith and Wilcock (2015) applied sediment accumulation in ponds and reservoirs to examine upland sediment sources and sinks in the Piedmont physiographic region of Maryland, USA. They reported that, if valley-bottom rates of sedimentation exceed erosion, then the proportion of watershed sediment delivery derived from stream banks is necessarily small. 
Reviewing the literatures showed that the separation of wash and suspended bed material load from total sediment load has been rarely taken into account throughout the globe. There is little information about the percentage of wash load in total sediment load in many watersheds worldwide. Therefore, studying the temporal variability of wash and bed material loads in Kojour River in the Educational and Research Forest Watershed of Tarbiat Modares University (TMU) was formulated to identify sediment sources, i.e., main river or watershed upland area in northern Iran. This study was planned to divide the entire sediment load at the main outlet of the watershed into bed material and wash load by three methods. This kind of division (based on origin of sediment) and use of three methods together, is the novelty of the work. The study was conducted in the above-mentioned watershed due to easy accessibility of the study area and existing supplementary information and data.

\section{Materials and methods}

\subsection{Study site}

The study was conducted in Kojour River in the Educational and Research Forest Watershed of TMU located in southeast of Nowshahr City in Mazandaran Province, Iran, lying between Caspian Sea from north and Alborz Mountain range from the south as shown in figure 1 . The watershed constitutes an area of about $500 \mathrm{~km}^{2}$. Elevation ranges from approx. 150 to $2650 \mathrm{~m}$ above mean sea level (Sadeghi and Saeidi 2010). Based on former studies (e.g., Sadeghi and Saeidi 2010), the watershed is deeply incised with a dominant hillslope gradient of 25-60\%. More than $90 \%$ of geology formations belong to second geological era. Soil in the watershed is brown forest soil, which is classified as Pesdogelly with loamy sand texture (Sadeghi and Saeidi 2010). According to the data collected from the nearest climatologic station of Nowshahr, the annual average precipitation of 1977-2007 was $1287.8 \mathrm{~mm}$ with the maximum and the minimum average monthly precipitation of 229.9 and 46.6 $\mathrm{mm}$ in October and July, respectively. The rainfall amount has oscillatory reducing mode from coastline to upstream of the watershed. In the highlands and in Kojour (upstream area), based on the statistical period of 2006-2008, the annual average precipitation reduces to approx. $313 \mathrm{~mm}$. Around $75 \%$ of the lower part of the watershed area is native deciduous forest, with the remainder developed mainly for livestock grazing in uplands. Land covers comprise Fagus orientalis, Alnus sp., Acer valetinum, Tillia begonifolia, Acer cappadocicum,
Parrotia persica and Diospyrus lotus. The average density cover in forest and rangeland areas is about 75 and $50 \%$, respectively.

\subsection{Sediment sampling}

To separate the wash load from the total sediment load, 24 suspended samples, bed load and channel materials were taken bi-weekly for a period of one year during June 2012-May 2013 from the main outlet at the Kojour River (figure 1). The flume gauges the watershed run-off and is used by local farmers to divert the flow to an earth fill dam constructed just few hundred metres below the main outlet. Only during severe floods (not occurred in the last 10 years and including the study period), water passes from the lower adjacent part of the flume. The suspended sediment samples were collected by deep integration method (Edwards and Glysson 1999). The duration of suspended sediment collection was controlled by the capacity of the sampler. The bed load sediment measurement was conducted by using a bed load trap (figure 2) especially designed, based on the dimensions of the flume and the changes recorded in the discharge at the outlet of the study watershed (Kheirfam and Sadeghi 2013). The bed load samplings were being prolonged for 20-30 min according to flow discharge with shorter periods for the lower flow discharges. The duration of bed load sampling was also controlled by the endurance of the sampler, since it was a tedious and hard work. The mean accuracy of the measurement was estimated to be more than 95\% (Kheirfam and Sadeghi 2013) by comparing the results of sampling and collection of the entire output run-off from the flume to a big barrel 250 litre) for four other separate study cases. At the same time, the samples of bed material loads were taken by Van-Vin Grap from three points, i.e., one from the bottom and two from the sides of river channel at the upper vicinity of the flume. The weight of bed material of the channel was approx. $1 \mathrm{~kg}$, depends on the capacity of the available grap. The flow discharges were then simultaneously measured through reading the flume scale and applying governing relationship between scale level and flow discharge for the flume under consideration.

\subsection{Sediment analyses}

The suspended sediment concentration was determined using the decantation and drying method (Sadeghi et al. 2008). The particle size distribution analyses were conducted by laser scattering particle size distribution HORIBA LA-950. 


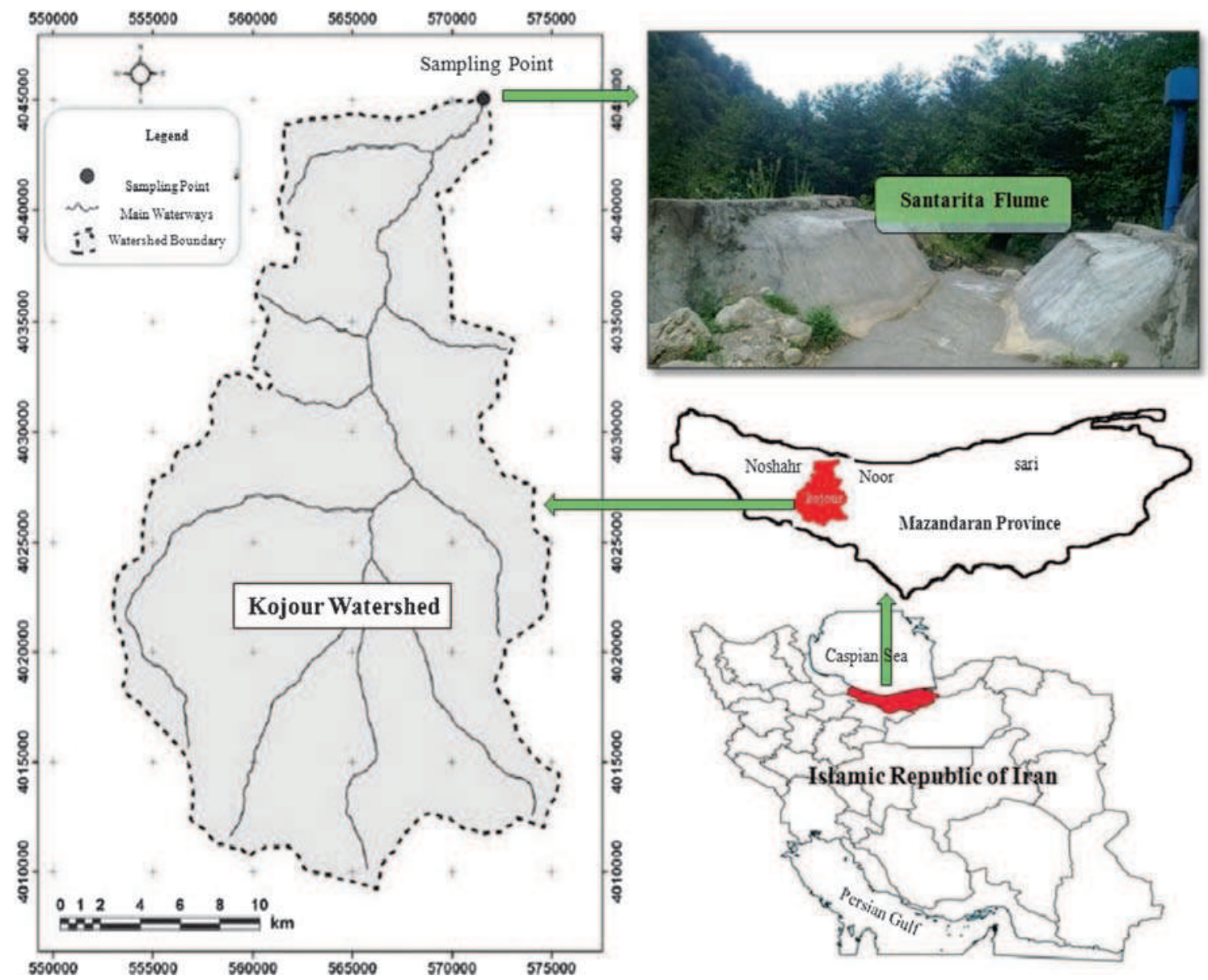

Figure 1. General view of the Educational and Research Forest Watershed of Tarbiat Modares University and sampling location at main outlet, Iran.

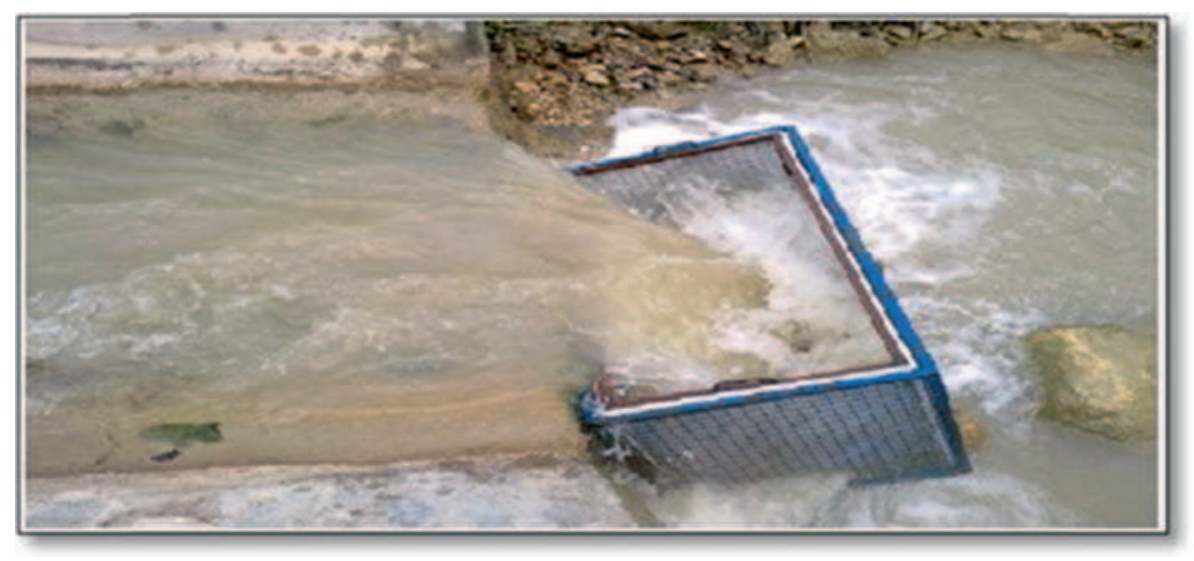

Figure 2. Bed load trap designed and constructed for the study.

\subsection{Data analyses and separation of sediments}

The data bank was developed in Excel 2010 software package. The suspended and channel particle size distribution curves and corresponding statistical analyses were also provided for the entire samples in the environment of the same software package and the other related analyses were conducted in IBM SPSS Statistics 19.

The entire samples were analyzed and corresponding particle size distribution curves were developed. The particle size distribution curves of suspended sediment were then compared with that of channel bed materials to separate wash and bed 
material loads. Three criteria of hydraulic engineers (Woo et al. 1986; Kuhnle 2013), Einstein method (Einstein 1950; Julien 2009) and lower limit of sediment particles in channel material (Poplawski et al. 1989) were used for the sediment load separation. In hydraulic and sediment transport engineering, the diameter limit of 63 microns (boundary between sand and silt) was considered as border between wash load and bed material load (Woo et al. 1986; Kuhnle 2013). In other words, the sediment particles larger than 63 microns in diameter were supposed as bed material load and particles smaller than 63 microns were considered as wash load. In Einstein method, 10\% of smallest sediment particles of channel material were considered as wash load and the other particles were considered as bed material load (Einstein 1950; Julien 2009). In lower limit of sediment particles in channel bed material method, part of suspended sediments that did not exist in channel material were considered as wash load and other particles were supposed as bed material load (Poplawski et al. 1989).

\section{Results}

The present study was conducted in the Educational and Research Forest Watershed of Tarbiat Modares University, Iran, in order to find out the partial contribution of different types of sediment loads in total sediment load reached the main outlet of the watershed. The study was conducted as per methodology explained above. The suspended and channel sediment curves for all samples collected during the study period are shown in figure 3 and corresponding descriptive results are represented in tables $1-3$.

\section{Discussion}

\subsection{Interpretation of results of wash and bed material loads separation}

\subsubsection{Hydraulic engineers method}

In this method, constant upper diameter of 63 micron (Kuhnle 2013) was considered as a boundary between silt (wash load) and sand (suspended bed material load). The results showed that the wash load concentration decreased from autumn to spring, summer and then winter with respective values of $0.80,0.590,0.261$ and $0.163 \mathrm{~g} \mathrm{l}^{-1}$. The suspended bed material load concentration also decreased from autumn to spring, winter and then summer with respective values of $0.025,0.002$, 0.001 and $0.0003 \mathrm{~g} \mathrm{l}^{-1}$. The maximum amount of suspended bed material load to wash load ratio was also in autumn and consequently declined from winter to spring and summer with respective values of $5.82,2.26,0.12$ and $0.09 \%$. The mean concentration of wash load, suspended bed material load and suspended bed material to wash load ratio for the entire samples taken during the study period were 0.454 and $0.007 \mathrm{~g} \mathrm{l}^{-1}$ and $2.26 \%$, respectively (table 3). Also the average amount of wash and suspended bed material load were 4712 and $46 \mathrm{t} \mathrm{y}^{-1}$, respectively. This ratio was very different from the figures reported by Belperio (1979) for Burdekin River in Australia, Poplawski et al. (1989) in Flinder River in Australia and also Walling et al. (2000) in the Tweed and the Humber watersheds in UK due to differences in climatic and hydrologic conditions and watershed physical characteristics as suggested by Dai and Lu (2014) and Singh et al. (2014). It is believed that most of the suspended sediments have been originated from upland areas of the watershed and therefore constituted wash loads.

\subsubsection{Einstein method}

According to channel sediment granulometry made for any sampling day, different limits were considered as boundary between wash and suspended bed material load (Einstein 1950; Julien 2009). This border switched to fine particles for July and August samples that occurred on account of nonexistence of rainfall and kept up base flow, ultimately led to depositing fine sediment in the river channel. This border then shifted to bigger particle on 5 September 2012 because of rainfall after a dry period and there was a reducing trend until 17 October 2012 (table 1 and figure 3). Overall, this border had different limits depending upon rainfall and time of sampling. In samples collected at the time of rainfall occurrence and river flow turbulence, this border had bigger limit than those collected during falling limb of hydrograph and in dry days as reported by Walling et al. (2000). However, in some samples, this pattern was not accurately followed due to differences in spatial distribution of rainfall and other special conditions in upland watershed. A similar finding has been reported by Gellis (2013) in four watersheds with different land uses in humid-tropical areas of Puerto Rico.

The results showed that the wash load concentration decreased from autumn to spring, summer and then winter with respective values of 0.815 , $0.542,0.261$ and $0.162 \mathrm{~g} \mathrm{l}^{-1}$ and the suspended bed material load concentration decreased from spring to autumn, winter and then summer with respective values of $0.012,0.011,0.003$ and $0.000 \mathrm{~g} \mathrm{l}^{-1}$. The maximum amount of suspended bed material 

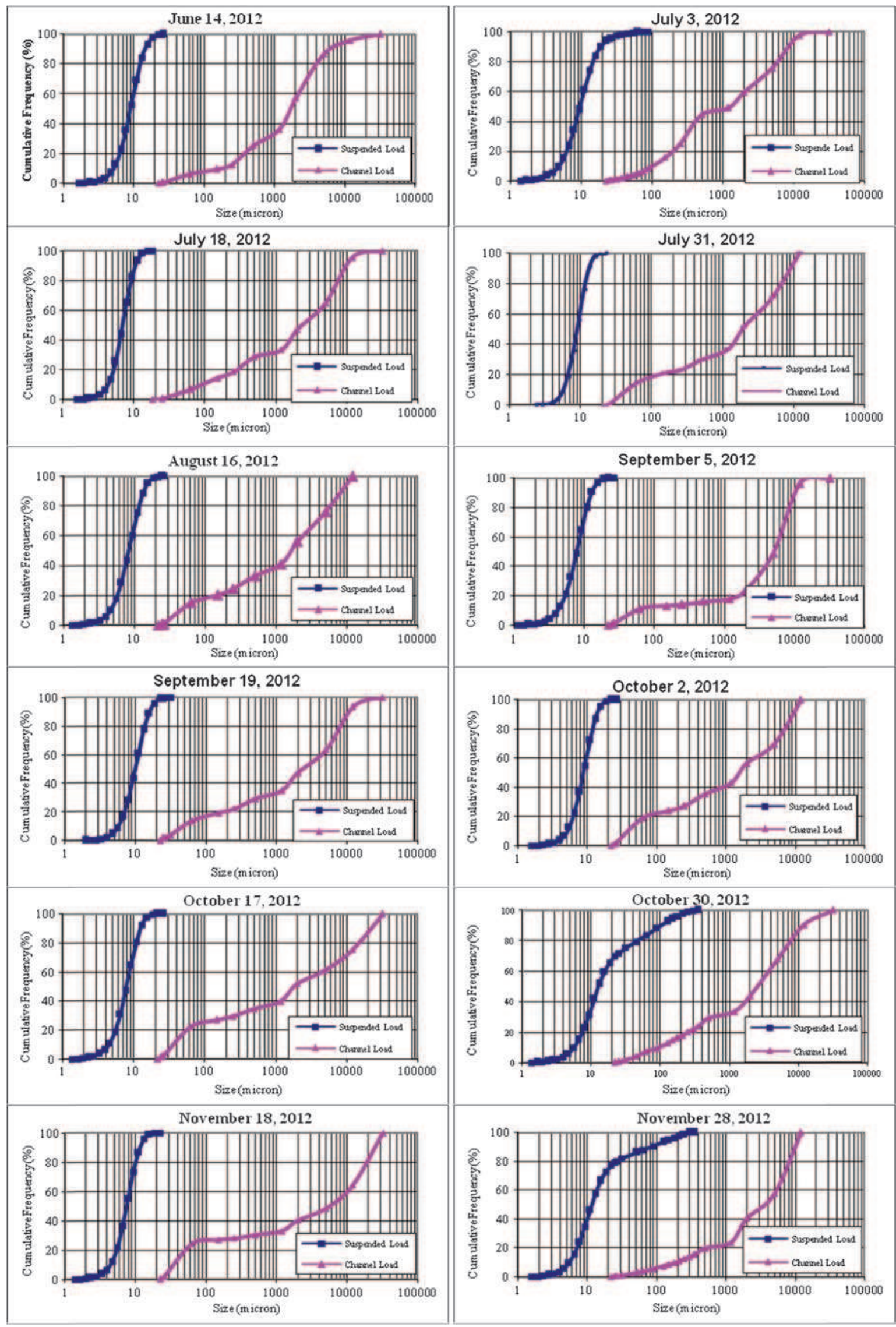

Figure 3. Suspended and channel sediment particle size distribution curves for samples taken from mean outlet of the Educational and Research Forest Watershed of Tarbiat Modares University, Iran. 

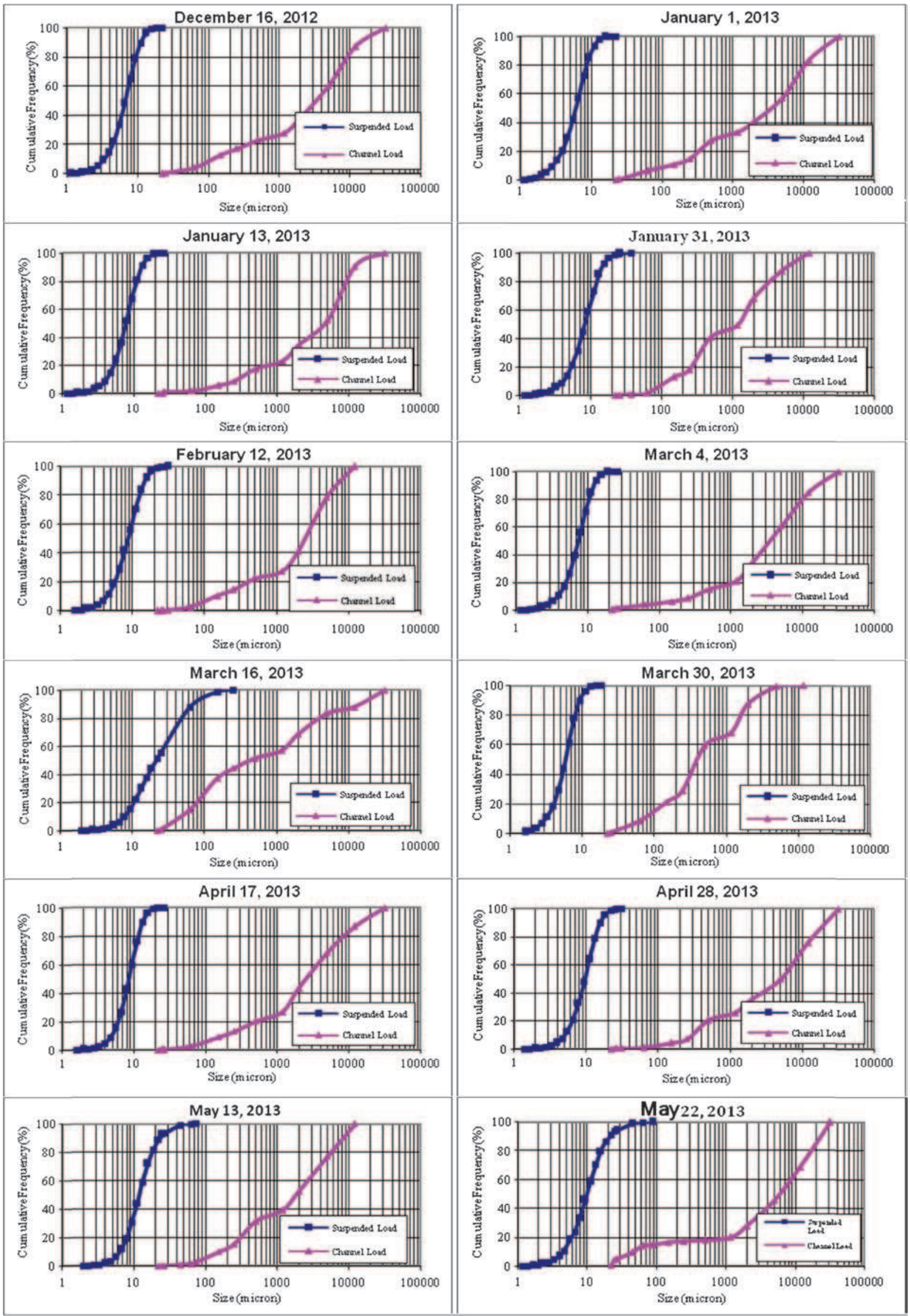

Figure 3. (Continued.) 
Table 1. Results of separation of wash and suspended bed material loads and bed load in Kojour River, Iran.

\begin{tabular}{|c|c|c|c|c|c|c|c|c|c|c|c|}
\hline \multirow[b]{3}{*}{ Sample } & \multirow[b]{3}{*}{ Date } & \multirow{3}{*}{$\begin{array}{c}\text { Bed load } \\
\text { concentration } \\
\left(\mathrm{g} \mathrm{l}^{-1}\right)\end{array}$} & \multicolumn{3}{|c|}{ Hydraulic engineers' method } & \multicolumn{3}{|c|}{ Einstein's method } & \multicolumn{3}{|c|}{$\begin{array}{c}\text { Lower limit of particles in channel } \\
\text { material method }\end{array}$} \\
\hline & & & \multirow[b]{2}{*}{$\begin{array}{l}\text { Boundary }^{\mathrm{a}} \\
\text { (micron) }\end{array}$} & \multicolumn{2}{|c|}{$\begin{array}{c}\text { Suspended sediment } \\
\text { concentration }\left(\mathrm{g} \mathrm{l}^{-1}\right)\end{array}$} & \multirow[b]{2}{*}{$\begin{array}{l}\text { Boundary }^{\mathrm{a}} \\
\text { (micron) }\end{array}$} & \multicolumn{2}{|c|}{$\begin{array}{c}\text { Suspended sediment } \\
\text { concentration }\left(\mathrm{g} \mathrm{l}^{-1}\right)\end{array}$} & \multirow[b]{2}{*}{$\begin{array}{c}\text { Boundary }^{\mathrm{a}} \\
\text { (micron) }\end{array}$} & \multicolumn{2}{|c|}{$\begin{array}{c}\text { Suspended sediment } \\
\text { concentration }\left(\mathrm{g} \mathrm{l}^{-1}\right)\end{array}$} \\
\hline & & & & $\begin{array}{l}\text { Wash } \\
\text { load }\end{array}$ & $\begin{array}{c}\text { Bed } \\
\text { material }\end{array}$ & & $\begin{array}{l}\text { Wash } \\
\text { load }\end{array}$ & $\begin{array}{c}\text { Bed } \\
\text { material }\end{array}$ & & $\begin{array}{l}\text { Wash } \\
\text { load }\end{array}$ & $\begin{array}{c}\text { Bed } \\
\text { material }\end{array}$ \\
\hline 1 & $14 / 06 / 2012$ & 0.00057 & \multirow{24}{*}{63} & 0.181 & 0.000 & 180 & 0.181 & 0.000 & \multirow{24}{*}{25} & 0.1807 & 0.0003 \\
\hline 2 & 03/07/2012 & 0.00170 & & 0.363 & 0.002 & 103 & 0.365 & 0.000 & & 0.3480 & 0.0170 \\
\hline 3 & $18 / 07 / 2012$ & 0.00106 & & 0.383 & 0.000 & 92 & 0.383 & 0.000 & & 0.3830 & 0.0000 \\
\hline 4 & $31 / 07 / 2012$ & 0.00075 & & 0.119 & 0.000 & 45 & 0.119 & 0.000 & & 0.1190 & 0.0000 \\
\hline 5 & $16 / 08 / 2012$ & 0.00062 & & 0.097 & 0.000 & 43 & 0.097 & 0.000 & & 0.0969 & 0.0001 \\
\hline 6 & 05/09/2012 & 0.00278 & & 0.123 & 0.000 & 57 & 0.123 & 0.000 & & 0.1229 & 0.0001 \\
\hline 7 & $19 / 09 / 2012$ & 0.00115 & & 0.482 & 0.000 & 47 & 0.482 & 0.000 & & 0.4800 & 0.0020 \\
\hline 8 & 02/10/2012 & 0.00154 & & 0.119 & 0.000 & 39 & 0.119 & 0.000 & & 0.1189 & 0.0001 \\
\hline 9 & $17 / 10 / 2012$ & 0.00004 & & 0.406 & 0.000 & 36 & 0.406 & 0.000 & & 0.4059 & 0.0001 \\
\hline 10 & $30 / 10 / 2012$ & 0.00230 & & 0.400 & 0.083 & 95 & 0.430 & 0.053 & & 0.3460 & 0.1370 \\
\hline 11 & $18 / 11 / 2012$ & 0.02811 & & 3.072 & 0.000 & 34 & 3.072 & 0.000 & & 3.0720 & 0.0000 \\
\hline 12 & $28 / 11 / 2012$ & 0.00165 & & 0.465 & 0.066 & 190 & 0.515 & 0.016 & & 0.4200 & 0.1110 \\
\hline 13 & $16 / 12 / 2012$ & 0.00034 & & 0.347 & 0.000 & 125 & 0.347 & 0.000 & & 0.3470 & 0.0000 \\
\hline 14 & $01 / 01 / 2013$ & 0.00156 & & 0.315 & 0.000 & 150 & 0.315 & 0.000 & & 0.3150 & 0.0000 \\
\hline 15 & $13 / 01 / 2013$ & 0.00119 & & 0.174 & 0.000 & 285 & 0.174 & 0.000 & & 0.1739 & 0.0001 \\
\hline 16 & $31 / 01 / 2013$ & 0.00110 & & 0.153 & 0.000 & 130 & 0.153 & 0.000 & & 0.1520 & 0.0010 \\
\hline 17 & $12 / 02 / 2013$ & 0.00009 & & 0.124 & 0.000 & 155 & 0.124 & 0.000 & & 0.1230 & 0.0010 \\
\hline 18 & 04/03/2013 & 0.00005 & & 0.156 & 0.000 & 300 & 0.156 & 0.000 & & 0.1559 & 0.0001 \\
\hline 19 & $16 / 03 / 2013$ & 0.00004 & & 0.059 & 0.008 & 49 & 0.051 & 0.016 & & 0.0370 & 0.0300 \\
\hline 20 & $30 / 03 / 2013$ & 0.00063 & & 0.116 & 0.000 & 74 & 0.116 & 0.000 & & 0.1160 & 0.0000 \\
\hline 21 & $17 / 04 / 2013$ & 0.00030 & & 0.044 & 0.000 & 180 & 0.044 & 0.000 & & 0.0439 & 0.0001 \\
\hline 22 & $28 / 04 / 2013$ & 0.00029 & & 0.038 & 0.000 & 295 & 0.038 & 0.000 & & 0.0378 & 0.0002 \\
\hline 23 & $13 / 05 / 2013$ & 0.00023 & & 0.024 & 0.001 & 165 & 0.025 & 0.000 & & 0.0230 & 0.0020 \\
\hline 24 & $22 / 05 / 2013$ & 0.01928 & & 2.910 & 0.010 & 40 & 2.850 & 0.070 & & 2.7400 & 0.1800 \\
\hline
\end{tabular}

${ }^{a}$ Boundary between wash and bed material loads. 
Table 2. Results of separation wash and suspended bed material loads and bed load in Kojour River, Iran.

\begin{tabular}{|c|c|c|c|c|c|c|c|c|c|c|}
\hline \multirow[b]{3}{*}{ Sample } & \multirow[b]{3}{*}{ Date } & \multirow{3}{*}{$\begin{array}{l}\text { Soft information of } \\
\text { general condition in } \\
\text { sampling days }\end{array}$} & \multirow{3}{*}{$\begin{array}{l}\text { Discharge } \\
(1 / \mathrm{s})\end{array}$} & \multirow{3}{*}{$\begin{array}{l}\text { Bed load-total } \\
\text { sediment load } \\
\text { ratio }(\%)\end{array}$} & \multicolumn{6}{|c|}{ Suspended sediment load-total sediment load ratio (\%) } \\
\hline & & & & & \multicolumn{2}{|c|}{ Hydraulic engineers' method } & \multicolumn{2}{|c|}{ Einstein's method } & \multicolumn{2}{|c|}{$\begin{array}{l}\text { Lower limit of particles in } \\
\text { channel material method }\end{array}$} \\
\hline & & & & & $\begin{array}{l}\text { Wash } \\
\text { load }\end{array}$ & $\begin{array}{c}\text { Bed } \\
\text { material }\end{array}$ & $\begin{array}{l}\text { Wash } \\
\text { load }\end{array}$ & $\begin{array}{c}\text { Bed } \\
\text { material }\end{array}$ & $\begin{array}{l}\text { Wash } \\
\text { load }\end{array}$ & $\begin{array}{c}\text { Bed } \\
\text { material }\end{array}$ \\
\hline 1 & $14 / 06 / 2012$ & Sunny & 190 & 0.31 & 99.69 & 0.00 & 99.69 & 0.00 & 99.53 & 0.16 \\
\hline 2 & $03 / 07 / 2012$ & Cloudy - light rainfall & 123 & 0.46 & 99.07 & 0.47 & 99.54 & 0.00 & 94.86 & 4.68 \\
\hline 3 & $18 / 07 / 2012$ & Cloudy & 135 & 0.28 & 99.72 & 0.00 & 99.72 & 0.00 & 99.72 & 0.00 \\
\hline 4 & $31 / 07 / 2012$ & Sunny & 93 & 0.62 & 99.38 & 0.00 & 99.38 & 0.00 & 99.38 & 0.00 \\
\hline 5 & $16 / 08 / 2012$ & Sunny & 85 & 0.64 & 99.36 & 0.00 & 99.36 & 0.00 & 99.29 & 0.07 \\
\hline 6 & $05 / 09 / 2012$ & Rainfall on past day after dry period & 145 & 2.21 & 97.79 & 0.00 & 97.79 & 0.00 & 97.77 & 0.02 \\
\hline 7 & $19 / 09 / 2012$ & Cloudy & 130 & 0.24 & 99.76 & 0.00 & 99.76 & 0.00 & 99.35 & 0.41 \\
\hline 8 & $02 / 10 / 2012$ & Sunny & 95 & 1.28 & 98.72 & 0.00 & 98.72 & 0.00 & 98.69 & 0.03 \\
\hline 9 & $17 / 10 / 2012$ & Sunny - Rainfall on past days & 130 & 0.01 & 99.99 & 0.00 & 99.99 & 0.00 & 99.98 & 0.01 \\
\hline 10 & $30 / 10 / 2012$ & Local sand harvesting from river & 205 & 0.47 & 83.40 & 16.13 & 88.80 & 10.73 & 71.40 & 28.13 \\
\hline 11 & $18 / 11 / 2012$ & Flood & 490 & 0.91 & 99.09 & 0.00 & 99.09 & 0.00 & 99.09 & 0.00 \\
\hline 12 & $28 / 11 / 2012$ & Rainfall & 185 & 0.31 & 87.40 & 12.29 & 96.70 & 2.99 & 78.93 & 20.74 \\
\hline 13 & $16 / 12 / 2012$ & Light rainfall & 170 & 0.10 & 99.90 & 0.00 & 99.90 & 0.00 & 99.90 & 0.00 \\
\hline 14 & $01 / 01 / 2013$ & Cloudy & 235 & 0.49 & 99.51 & 0.00 & 99.51 & 0.00 & 99.51 & 0.00 \\
\hline 15 & $13 / 01 / 2013$ & Cloudy & 160 & 0.68 & 99.32 & 0.00 & 99.32 & 0.00 & 99.24 & 0.08 \\
\hline 16 & $31 / 01 / 2013$ & Cloudy & 140 & 0.72 & 99.28 & 0.00 & 99.28 & 0.00 & 98.69 & 0.59 \\
\hline 17 & $12 / 02 / 2013$ & Sunny & 120 & 0.07 & 99.93 & 0.00 & 99.93 & 0.00 & 99.43 & 0.50 \\
\hline 18 & $04 / 03 / 2013$ & Cloudy & 130 & 0.03 & 99.97 & 0.00 & 99.97 & 0.00 & 99.96 & 0.01 \\
\hline 19 & $16 / 03 / 2013$ & Rainfall & 130 & 0.06 & 87.62 & 12.32 & 75.69 & 24.25 & 55.26 & 44.68 \\
\hline 20 & $30 / 03 / 2013$ & Cloudy & 145 & 0.54 & 99.46 & 0.00 & 99.46 & 0.00 & 99.46 & 0.00 \\
\hline 21 & $17 / 04 / 2013$ & Light rainfall & 240 & 0.67 & 99.33 & 0.00 & 99.33 & 0.00 & 99.31 & 0.02 \\
\hline 22 & $28 / 04 / 2013$ & Sunny & 270 & 0.77 & 99.33 & 0.00 & 99.23 & 0.00 & 98.78 & 0.45 \\
\hline 23 & $13 / 05 / 2013$ & Sunny & 185 & 0.74 & 98.93 & 0.33 & 99.26 & 0.00 & 91.81 & 7.45 \\
\hline 24 & $22 / 05 / 2013$ & Flood & 450 & 0.65 & 99.10 & 0.25 & 96.90 & 0.45 & 99.16 & 0.19 \\
\hline Average & - & - & 182.54 & 0.55 & 97.71 & 1.74 & 97.85 & 1.60 & 94.94 & 4.51 \\
\hline S.D. & - & - & 100.34 & 0.48 & 0.794 & 0.020 & 0.790 & 0.018 & 0.776 & 0.050 \\
\hline
\end{tabular}


Table 3. Statistical variables of wash and suspended bed material loads at different time periods.

\begin{tabular}{|c|c|c|c|c|c|c|c|c|c|c|}
\hline \multirow[b]{2}{*}{ Time period } & \multirow[b]{2}{*}{$\begin{array}{c}\text { Statistical } \\
\text { variable }\end{array}$} & \multicolumn{3}{|c|}{ Wash load* $\left(\mathrm{g} \mathrm{l}^{-1}\right)$} & \multicolumn{3}{|c|}{ Suspended bed material load* $\left(\mathrm{g} \mathrm{l}^{-1}\right)$} & \multicolumn{3}{|c|}{ Suspended bed material load-wash load ratio* $(\%)$} \\
\hline & & $\begin{array}{c}\text { Hydraulic } \\
\text { engineers' } \\
\text { method }\end{array}$ & $\begin{array}{c}\text { Einstein's } \\
\text { method }\end{array}$ & $\begin{array}{c}\text { Lower limit of } \\
\text { particles in channel } \\
\text { material method }\end{array}$ & $\begin{array}{c}\text { Hydraulic } \\
\text { engineers' } \\
\text { method }\end{array}$ & $\begin{array}{c}\text { Einstein's } \\
\text { method }\end{array}$ & $\begin{array}{c}\text { Lower limit of } \\
\text { particles in channel } \\
\text { material method }\end{array}$ & $\begin{array}{c}\text { Hydraulic } \\
\text { engineers' } \\
\text { method }\end{array}$ & $\begin{array}{c}\text { Einstein's } \\
\text { method }\end{array}$ & $\begin{array}{l}\text { Lower limit of } \\
\text { particles in channel } \\
\text { material method }\end{array}$ \\
\hline \multirow[t]{3}{*}{ Spring $(\mathrm{N}=6)$} & Min & 0.038 & 0.025 & 0.023 & 0.0000 & 0.000 & 0.000 & 0.00 & 0.00 & 0.00 \\
\hline & Max & 2.910 & 2.850 & 2.740 & 0.0100 & 0.070 & 0.180 & 0.40 & 2.46 & 8.69 \\
\hline & Mean & 0.590 & 0.542 & 0.523 & 0.0020 & 0.012 & 0.030 & 0.12 & 0.41 & 2.70 \\
\hline \multirow[t]{3}{*}{ Summer $(\mathrm{N}=6)$} & Min & 0.097 & 0.097 & 0.097 & 0.0000 & 0.000 & 0.000 & 0.000 & 0.000 & 0.000 \\
\hline & Max & 0.482 & 0.482 & 0.480 & 0.0020 & 0.000 & 0.017 & 0.22 & 0.00 & 4.88 \\
\hline & Mean & 0.261 & 0.261 & 0.258 & 0.0003 & 0.000 & 0.003 & 0.09 & 0.00 & 0.91 \\
\hline \multirow[t]{3}{*}{ Autumn $(\mathrm{N}=6)$} & Min & 0.119 & 0.119 & 0.1189 & 0.0000 & 0.000 & 0.000 & 0.00 & 0.00 & 0.00 \\
\hline & $\operatorname{Max}$ & 3.072 & 3.072 & 3.072 & 0.0830 & 0.053 & 0.137 & 20.75 & 12.32 & 39.59 \\
\hline & Mean & 0.801 & 0.815 & 0.784 & 0.0250 & 0.011 & 0.041 & 5.82 & 2.57 & 11.02 \\
\hline \multirow[t]{3}{*}{ Winter $(\mathrm{N}=6)$} & Min & 0.059 & 0.051 & 0.037 & 0.0000 & 0.000 & 0.000 & 0.00 & 0.00 & 0.00 \\
\hline & Max & 0.315 & 0.315 & 0.315 & 0.0080 & 0.016 & 0.030 & 13.56 & 31.37 & 81.08 \\
\hline & Mean & 0.163 & 0.162 & 0.159 & 0.0010 & 0.003 & 0.005 & 2.26 & 5.23 & 13.78 \\
\hline \multirow[t]{3}{*}{ Year $(\mathrm{N}=24)$} & Min & 0.038 & 0.025 & 0.023 & 0.0000 & 0.000 & 0.000 & 0.00 & 0.00 & 0.00 \\
\hline & $\operatorname{Max}$ & 3.072 & 3.072 & 3.072 & 0.0830 & 0.070 & 0.180 & 13.56 & 31.37 & 81.08 \\
\hline & Mean & 0.454 & 0.445 & 0.431 & 0.0070 & 0.006 & 0.020 & 2.26 & 2.05 & 7.10 \\
\hline
\end{tabular}

*All figures have been calculated based on the entire data collected for the study scale. 
load to wash load ratio was also in winter and consequently declined from autumn to spring and summer with respective values of $5.23,2.57,0.41$ and $0.00 \%$. The mean concentration of wash load, suspended bed material load and suspended bed material to wash load ratio for the entire samples taken during the study period were 0.445 and $0.006 \mathrm{~g} \mathrm{l}^{-1}$ and $2.05 \%$, respectively (table 3 ). Different ratios with temporal variations have also been implied by Belperio (1979), Poplawski et al. (1989) and Walling et al. (2000) among wash, suspended and bed loads.

\subsubsection{Lower limit of particles in channel material method}

According to the granulometric analyses of collected samples, the particles finer than 25 micron did not constitute more than $1 \%$ in all the samples collected from channel material of Kojour River, but suspended sediment particles existed in bulk. Therefore, the diameter of 25 micron was considered as boundary between wash and suspended bed material loads in this method. Whereas, Poplawski et al. (1989) estimated this border as 150 micron in Flinder River in Australia. Based on the results obtained through applying this approach, the wash load concentration decreased from autumn to spring, summer and then winter with respective values of $0.784,0.523,0.258$ and $0.129 \mathrm{~g} \mathrm{l}^{-1}$. The suspended bed material load concentration also decreased from autumn to spring, winter and then summer with respective values of $0.041,0.030$, 0.005 and $0.003 \mathrm{~g} \mathrm{l}^{-1}$. The maximum amount of suspended bed material load to wash load ratio was also in winter and consequently declined from autumn to spring and summer with respective values of $13.78,11.02,2.7$ and $0.91 \%$. Temporal variations of sediment loads have been reported by Belperio (1979), Poplawski et al. (1989), Walling et al. (2000) and Dai and Lu (2014) from different parts of the world. The mean concentration of wash load, suspended bed material load and suspended bed material to wash load ratio for the entire samples taken during the study period were 0.431 and $0.02 \mathrm{~g} \mathrm{l}^{-1}$ and $7.1 \%$, respectively (table 3 ).

\subsection{Comparison of results of load separation}

The results showed that more than $98 \%$ of suspended sediment particles have diameter less than 63 micron. It agrees with Walling et al. (2000) who reported that approx. more than $95 \%$ of load particles in Humber and Tweed Rivers in UK were smaller than 63 microns. Decreasing pattern of sediment concentration in winter and spring proceeded from reducing sediment load released from surface watershed to the drainage networks on account of the elapse of long period from the onset of rainfall. It corresponded with the results of Periago and Soto (2004), Gellis (2013) and Dai and $\mathrm{Lu}$ (2014) who reported reducing sediment load after consecutive floods. In addition, growing plant cover lead to reduced soil erosion and sediment production in surface watershed. The result also showed that the maximum concentration of wash load occurred in autumn attributed to erosive rainfalls occurred in autumn in Iran. This was in same line with the findings reported by Yuill and Gasparini (2011) emphasizing larger effects of rainfall than run-off on wash load concentration.

In the first sample after dry period of summer on September 5, 2012, suspended bed material load concentration did not rise, but bed load concentration greatly did. This was probably related to one day lag between sample collection and rainfall, but samples on 3 July, 28 November, 16 March and 22 May 2012 were collected during rainfall on the study area or just after a short time of rainfall event. On 30 October 2012, the sample was collected after local sand and gravel harvesting from river bed led to a rising pattern in suspended bed material load concentration. So that, increasing stream power in rainfall events and increasing suspended sediment concentration, caused the water density to be increased and caused further bed material transport. It agreed with Walling et al. (2000) who believed that the transportation of bed material loads has been influenced by increasing water velocity and shear stress during rainfall events and flood periods. Accordingly, the relationships between suspended (SSC, $\mathrm{g} \mathrm{l}^{-1}$ ) and bed (BLC, $\mathrm{g} \mathrm{l}^{-1}$ ) loads with discharge $\left(\mathrm{Q}, \mathrm{l} \mathrm{s}^{-1}\right)$ have been regressed in equations (1) and (2):

$$
\begin{aligned}
& \mathrm{SSC}=1.264 \mathrm{Q}-3.488 \quad r=0.472, p=0.020 \text {, } \\
& \mathrm{BLC}=1.960 \mathrm{Q}-7.490 \quad r=0.520, p=0.009 \text {. }
\end{aligned}
$$

The result of correlation between discharge and wash and suspended bed material loads and the result of one-way ANOVA to compare calculated wash load from different methods have also been represented in tables 4 and 5, respectively.

According to results of table 4, discharge was an important factor on wash load concentration in all three methods. It was significant at 0.01 level for hydraulic engineers' method and was significant at 0.05 level for Einstein and lower limit of particles in channel material methods. It is in agreement with Wilcock et al. (2009), but contradicts Yuill and Gasparini (2011). In addition, calculated suspended bed material load concentration did not have significant correlation with discharge as mentioned by Yuill and Gasparini (2011). The results further showed that the suspended bed material load had complex characteristics 
Table 4. Results of correlation between discharge and sediment loads from different methods (N=24).

\begin{tabular}{|c|c|c|c|c|c|}
\hline Method & & & Discharge & Wash load & $\begin{array}{l}\text { Suspended bed } \\
\text { material load }\end{array}$ \\
\hline Hydraulic engineers & & $\begin{array}{l}\text { Pearson correlation } \\
\text { Sig. (2-tailed) }\end{array}$ & 1 & $\begin{array}{l}0.535^{* *} \\
0.007\end{array}$ & $\begin{array}{c}-0.174 \\
0.417\end{array}$ \\
\hline Einstein & Discharge & $\begin{array}{l}\text { Pearson correlation } \\
\text { Sig. (2-tailed) }\end{array}$ & 1 & $\begin{array}{l}0.470^{*} \\
0.020\end{array}$ & $\begin{array}{r}-0.243 \\
0.253\end{array}$ \\
\hline $\begin{array}{l}\text { Lower limit of particles } \\
\text { in channel material }\end{array}$ & & $\begin{array}{l}\text { Pearson correlation } \\
\text { Sig. (2-tailed) }\end{array}$ & 1 & $\begin{array}{l}0.464^{*} \\
0.022\end{array}$ & $\begin{array}{l}0.277 \\
0.190\end{array}$ \\
\hline
\end{tabular}

* and ${ }^{* *}$ denote correlation is significant at 0.05 and 0.01 levels (2-tailed), respectively.

Table 5. Result of one way ANOVA to compare calculated wash load in different methods.

\begin{tabular}{lccccc}
\hline & $\begin{array}{c}\text { Sum of } \\
\text { squares }\end{array}$ & $\begin{array}{c}\text { Degree of } \\
\text { freedom }\end{array}$ & $\begin{array}{c}\text { Mean } \\
\text { square }\end{array}$ & F-value & $\begin{array}{c}\text { Significant } \\
\text { level }\end{array}$ \\
\hline Between groups & 0.043 & 2 & 0.022 & 0.088 & 0.916 \\
Within groups & 17.111 & 69 & 0.248 & & \\
Total & 17.154 & 71 & & & \\
\hline
\end{tabular}

compared to wash and bed loads and therefore discharge alone is not enough to control it. Anecdotal evidences from observed data and soft information collected during samplings suggested a recognized contribution of human interference to stream sediment. This agreed with Gellis (2013) and Dai and $\mathrm{Lu}$ (2014) who reported that the sediment availability increased after human disturbance and disagreed Yang and Simoes (2005) who reported that the bed material load transport capacity was only related to hydraulic conditions and amount of wash load. In addition, the bed load transportation mainly was controlled by stream power, which itself was influenced by flow discharge. The results of the ANOVA analyses also showed that the calculated wash loads from all three methods were not significantly different $(p=0.916)$.

\section{Conclusions}

The results of this study demonstrated that during one year sampling (2011-2012), the wash load, suspended bed material and bed loads, respectively contributed $96.8,2.65$ and $0.55 \%$ of the total load reaching the main outlet of the Educational and Research Forest Watershed of Tarbiat Modares University, Iran. The wash load had the maximum contribution (about 97\%) in sediment yield, though it varied from time to time. It can be concluded that the watershed surface had more role in the generation of total sediment load reaching the main outlet of the study watershed. In addition, the results showed that the discharge had different effects on different components of sediment loads.
Bed load and wash load were correlated with discharge, but the suspended bed material load had little correlation with it.

The authors hope that this study will encourage other researchers and watershed administrators to conduct similar in-depth studies for longer periods to identify sources of sediment loads. This will improve the understanding of fluvial behaviour leading to better management of watersheds.

\section{Acknowledgements}

The authors would like to acknowledge Dr A Najafi, In-Charge for the Educational and Research Forest Watershed of Tarbiat Modares University; Mrs. Habibi and Engr. S Boor (Technical Assistant of Watershed Management Department Laboratory) for their laboratory help; Messrs. Qazvini, Shabani, Shalikar, Kheirfam, NoorMohamadi, Khosrobeigi, Janizadeh and Rahmati, and Miss. Gharamahmoodli for their field assistance. This research has also been partly supported by the Iran National Science Foundation (Project no. 12-10100012).

\section{References}

Belperio A P 1979 The combined use of wash load and bed material load rating curves for the calculation of the total load: An example from the Burdekin River, Australia; Catena 6 317-329.

Dai S B and Lu X X 2014 Sediment load change in the Yangtze River (Changjiang): A review; Geomorphology 215 6073, http://dx.doi.org/10.1016/j.geomorph.2013.05.027.

Edwards T K and Glysson G D 1999 Field methods for measurement of fluvial sediment; USGS Open-file Report Book 3 (Chapter 2) 1-97. 
Einstein H 1950 The bed-load function for sediment transportation in open channel flow; United States Department of Agriculture, Washington DC, Technical Bulletin No. 1026, 78p.

Gellis A C 2013 Factors influencing storm-generated suspended-sediment concentrations and loads in four basins of contrasting land use, humid-tropical Puerto Rico; Catena 104 39-57.

Graf W L, Clark S L, Krammerer M T, Lehman T, Randall K and Schroeder R 1991 Geomorphology of heavy metals in the sediments of Queen Creek, Arizona, USA; Catena $18567-582$.

Hergault V, Frey $\mathrm{Ph}$ and Ois Métivier F 2010 Image processing for the study of bedload transport of two-size spherical particles in a supercritical flow; Exp. Fluids 49 1095-1107.

Julien P Y 2009 Fluvial transport of suspended solids; Encyclopedia of Inland Waters 1 681-683.

Kheirfam H and Sadeghi S H R 2013 Effect of sand and gravel mining on granulometry of bed load in Kojour River; In: Proceedings of National Seminar on Integrated Watershed Management and National Production, Malayer University, Iran, 21 February, 2013: 40 (in Persian).

Kuhnle R A 2013 Suspended load; Treatise on Geomorphology 9 124-136.

Lefrançois J, Grimaldi C, Gascuel-Odoux C and Gilliet N 2007 Suspended sediment and discharge relationships to identify bank degradation as a main sediment source on small agricultural catchments; Hydrol. Process. 21(21) 2923-2933.

Milhous R T 1998 Modeling of instream flow needs: The link between sediment and aquatic habitat; Regulated Rivers: Res. Manag. 14 79-94.

Miller J R 1997 The role of fluvial geomorphic processes in the dispersal of heavy metals from mine sites; J. Geochem. Explor. 58 101-118.

Novotny V 1980 Delivery of suspended sediment and pollutants from nonpoint sources during overland flow; Water Resour. Bull. 16 1057-1065.

Periago E L and Soto B 2004 Modeling wash load transport of soil in a headwater catchment cultivated by non-tillage methods; J. Hydrol. 287 19-33.
Poplawski W A, Piorewics J and Gourlay M R 1989 Sediment transport in an inland river in North Queensland; Hydrobiologia 176/177 77-92.

Sadeghi S H R, Kiani Harchegani M and Yunesi H A 2012 Suspended sediment concentration and particle size distribution and their relationship with heavy metal content; J. Earth Syst. Sci. 121 63-71.

Sadeghi S H R, Mizuyama T, Miyata S, Gomi T, Kosugi K, Fukushima T, Mizugaki S and Onda Y 2008 Determinant factors of sediment graphs and rating loops in a reforested watershed; J. Hydrol. 356 271-282.

Sadeghi S H R and Saeidi P 2010 Reliability of sediment rating curves for a deciduous forest watershed in Iran; Hydrol. Sci. J. 55(5) 821-831.

Singh P K, Bhunya P K, Mishra S K and Chaube U C 2008 A sediment graph model based on SCS-CN method; J. Hydrol. 349(1-2) 244-255.

Singh V B, Ramanathan A L, Pottakkal J G and Kumar M 2014 Seasonal variation of the solute and suspended sediment load in Gangotri glacier melt water, central Himalaya; J. Asian Earth Sci. 79(Part A) 224-234.

Smith S M C and Wilcock P R 2015 Upland sediment supply and its relation to watershed sediment delivery in the contemporary mid-Atlantic Piedmont (USA); Geomorphology 232 33-46.

Vanoni V A 1975 Sedimentation Engineering; Headquarters of the Society, 745p.

Walling D E, Owens P N, Waterfall B D, Leeks G J and Wass P D 2000 The particle size characteristics of fluvial suspended sediment in the Humber and Tweed catchments, UK; Sci. Total Environ. 251 205-222.

Wilcock P, Pitlick J and Cui Y 2009 Sediment transport primer estimating bed-material transport in gravel-bed rivers; United States Department of Agriculture, 78p.

Woo H S, Julien P Y and Richardson E V 1986 Wash load and fine sediment load; J. Hydraul. Eng. 112(6) 541545.

Yang C T and Simoes F J M 2005 Wash load and bedmaterial load transport in the Yellow River; J. Hydraul. Eng. 131(5) 413-418.

Yuill B T and Gasparini N M 2011 Hydrologic controls on wash load sediment concentrations within a low-ordered, ephemeral watershed; J. Hydrol. 410 73-83. 